\title{
Resolving the Korean Conflict through a Combination of Human Rights and Human Security
}

\author{
Bo-hyuk Suh
}

\begin{abstract}
Why has the division-armistice system lasted over 70 years in the Korean Peninsula? It could be said that the system has been sustained by the existence of forces that still remain to support the division of the peninsula by reproducing distrust and a sense of animosity. For instance, the continuing confrontations and conflicts over human rights between the two Koreas are remnants of the Cold War. Exploiting peace and security issues for political gains by the two division powers also demonstrates the continuation of the division-armistice system. How can the protracted conflict under this system be overcome? This study analyzes the characteristics of the protracted conflict in the Korean Peninsula and explores alternatives from a macro-critical perspective. The author attempts to answer this research question by paying attention to the synergistic effects of human rights and security. The politicization of human rights and continuing militarism are manifestations of the negative synergistic effects of the norms under the division-armistice system. Including security in human rights and embracing human rights in peace are essential for transforming these negative synergistic effects into positive effects toward developing a sustainable peace. Human security and the right to peace are proposed here as alternatives for creating positive synergistic effects. In resolving the Korean conflict, it is becoming increasingly important to make efforts in improving inter-Korean relations, promoting peaceful and democratic transition in North Korea, and increasing civilian control of the military in all countries concerned.
\end{abstract}

Key Words: division system, human rights, human security, right to peace inter-Korean relations

$\mathrm{W}$ hy is the Korean conflict proving so endlessly intractable? Conflict in a society not only has many background elements, such as history, culture, politics, and economics, but also involves such diverse aspects as ethnicity, class, ide-

*Bo-hyuk Suh(suhbh21@gmail.com) is a Humanities Korea (HK) Research Professor at the Institute for Peace and Unification Studies (IPUS) of Seoul National University. For over 10 years, he has been studying peace and human rights issues in the context of Korean Peninsula, while attempting to extend his interests into peace studies. His recent writings include Division Violence (Co-ed. Korean, 2016), Asia-Pacific between Conflict and Reconciliation (Co-author 2016), and North Korean Human Rights: Crafting a More Effective Framework (2016, Forthcoming).

This work was supported by a National Research Foundation of Korea grant funded by the Korean Government (NRF-2010-361-A0o017).

The Korean Journal of International Studies Vol.14, No.1 (April 2016), 53-75.

http://dx.doi.org/10.14731/kjis.2016.4.14.1.53

(c) 2016 The Korean Association of International Studies 
ology and foreign relations. The term 'Korean conflict' can be viewed as a general term applicable to almost every conflict on the divided Korean Peninsula. However, it usually refers to the confrontations, as well as military tensions, between North and South Korea, which have deep roots in the nation's postWorld War II division and the armistice system developed as a result of the Korean War. The Korean conflict has a complex background involving politics, ideology, and the military. The formative elements and reality of the Korean conflict are directly related to international politics and the peninsula's surrounding superpowers; therefore, it is erroneous to reduce the meaning of the Korean conflict to just a confrontation between North and South Korea. The 70 years of division of Korea into South and North has led to different thought processes about the conflict, as well as discrepancies involving political and economic issues; however, these will not be dealt in this paper. Nevertheless, it is necessary to mention that many elements within North and South Korean societies are closely related to the division-armistice system.

To discuss the characteristics of the Korean conflict, it is necessary to explore human rights and security issues and their resultant negative synergistic effects. The different perspectives between North and South Korea on human rights issues reflect the two opposing parties' world views during the Cold War; furthermore, military tensions under the armistice system are part of a traditional security dilemma. As the politics of human rights and militarism have developed, both parties have participated in, and perpetuated, the Korean conflict. Is it difficult for human rights and security to coexist? Will it be hard to overcome these negative synergistic effects? If it is possible, how will it be accomplished? By analyzing the Korean conflict, this paper will attempt to answer these questions. ${ }^{1}$

\section{CONFLICTS IN THE PERSPECTIVES OF HUMAN RIGHTS}

It is conventional wisdom that human rights are universal and specific human rights are created by the awakening and struggle of oppressed peoples. Denied or confirmed by political perspectives and understanding, the universality of human rights has been slowly extended throughout modern history. During the Cold War, while the liberalist camp stressed civil and political rights (CPR) and indi-

\footnotetext{
${ }^{1}$ There are some existing studies on human security and the right to peace in the context of the Korean Peninsula, respectively, such as Lim (2011, 167-210), Kyoung-Joo Lee (2014), Yu (2011, 221241), Bernaldez $(2011,5-31)$ and Lee (2008, 411-434). However, the interaction or combination of these two concepts seldom has been studied.
} 
vidual rights, the socialist camp was more concerned with economic, social, and cultural rights (ESCR) and collective rights. The two camps were in opposition (Ishay 2008; Hunt 2008). The division of the Korean Peninsula caused by the Cold War led to a difference in human rights perspectives between North and South Korea. While the dismantlement of Cold War structures and organizations seems to be evidence of the victory of the liberal human rights perspective, the conflict surrounding these human rights perspectives has not diminished due to continued confrontation between the two Koreas in the Korean Peninsula.

Since democratization in 1987, the Republic of Korea (ROK or South Korea), which in a short period of time has made remarkable improvements within the areas of democracy and human rights, has upheld the universal value of human rights as a centerpiece of its foreign policy goals. As a party to seven core international human rights conventions, including the International Covenant on Civil and Political Rights (ICCPR) and the International Covenant on Economic, Social and Cultural Rights (ICESCR), South Korea is earnestly striving to implement the provisions of the relevant conventions at the national level through collaborative partnerships with various stakeholders. In particular, by paying special attention to the rights of vulnerable persons such as women, children, and persons with disabilities, the ROK has achieved substantial improvements in the equal and effective enjoyment of human rights. Furthermore, South Korea has proactively participated in the activities of the United Nations (UN) Human Rights Council and the UN General Assembly, working closely with the international community for the protection and promotion of human rights around the world. ${ }^{2}$ Since the inauguration of Lee Myung-bak government in 2008, however, the human rights situation in South Korea-especially freedom of conscience, assembly and association, and expression-has become increasingly strained, causing deep concern from the international community, as well as South Koreans.

The fact that South Koreans generally have a universal perspective on human rights has been shown in a series of polls. In the annual "Research on Unification Awareness" survey conducted by the Institute for Peace and Unification Studies (IPUS) at Seoul National University, which has been conducted since 2007, the most urgent task for unification is "North Korean human rights improvement" along with such other responses as "a lessening of tension in the Korean Peninsula." (Park 2013, 86-87) Grounded in the universality of human rights, the South Korean government sympathizes with international concerns about the seriousness of the North Korean human rights situation and supports, as well as

\footnotetext{
${ }^{2}$ See Ministry of Foreign Affairs of Korea (2016).
} 
actively joins, the efforts of the international community to improve the situation. The South Korean government has taken a stance on the North Korean human rights situation, stating: "Human rights are a universal value and should be dealt solely as a human rights issue and not along with any other issue."3 South Korea has been actively engaged in international cooperative efforts for the improvement of human rights in the Democratic People's Republic of Korea (DPRK or North Korea). It has been a co-sponsor since 2008 of the UN Resolution on the Situation of Human Rights in the DRPK at the UN General Assembly and the Human Rights Council. Recently, the international community has expressed grave concern over the human rights situation in the DPRK. In March 2013, the UN Human Rights Council decided to establish the Commission of Inquiry (COI) on Human Rights in the DPRK. South Korea has been strongly supportive of the strengthening of UN mechanisms to implement the Commission's recommendations. The ROK actively looks to taking on the leading role as Special Rapporteur on the human rights situation in the DPRK, and also has played an instrumental role in establishing the Commission. Regarding the scores of North Koreans who are leaving the DPRK to survive and search for freedom, South Korea has been calling on all countries to uphold the international legal principle of non-refoulement and to grant rightful protection to those refugees and asylum-seekers so that they can live dignified lives of their own accord (Yun 2014).

In contrast to the human rights of South Korea, North Korea's condition seems anachronistic. North Korea has recognized human rights in terms of classism, collectivism, and relativism. Given that the DPRK is a member of the United Nations and has joined five international human rights conventions, it is of course hard to understand why North Korea has ignored the universality of human rights. In spite of this, North Korea has not lowered its political sensitivity regarding human rights issues. North Korea has not denied the universalism of human rights nominally, instead taking a relativist view. The DPRK is afraid of double standards and the politicization of human rights.

First, the DPRK regards national sovereignty and dignity as its lifeblood and places national sovereignty above human rights. Looking at how collective rights are prioritized over individual rights can shed some light on the perspective that human rights are subordinate to national sovereignty.

Second, North Korea's attitude toward the mechanisms of international human rights is also dependent on the outside world's recognition of North Korea's national sovereignty. For example, a state agency of human rights called the

\footnotetext{
${ }^{3}$ See Ministry of Foreign Affairs of Korea (2016).
} 
Chosun Human Rights Association expressed North Korea's willingness to reopen human rights dialogue with the international community, including South Korea (Chosun Human Rights Association 2014, 123). A human rightsrelated dialogue took place between the DPRK and the European Union between 1998 and 2004, during which a North Korean diplomat in Geneva indicated, "There was no reason whatsoever for those countries to unilaterally and deliberately ignore this ongoing process of human rights dialogue and cooperation and to resort to hostility and confrontation had they not really been harboring ulterior motives against the Democratic People's Republic of Korea."4

Third, North Korea asserted that the COI and the Special Rapporteur run counter to the current trends against politicization and moving towards genuine dialogue and cooperation in the area of human rights. Different from the Universal Periodic Review (UPR), which was introduced in 2006 when the Human Rights Council was established, country-specific mandates such as the COI and Special Rapporteur mechanisms were viewed by the DPRK as a breeding ground for politicization, selectivity, and double standards. The North Korean government strongly denounced the $\mathrm{COI}$ as a product of a politically-motivated confrontation and a conspiracy that had no relevance to human rights. The DPRK has also strongly criticized double standards with regards to the human rights records of the most powerful states in the international system, to include the U.S. invasion of Afghanistan and Iraq and biased attitudes concerning the IsraeliPalestinian conflict. In this context, North Korea insists that international human rights organizations and western countries have oppressed innocent countries like the DPRK. Not addressing the above mentioned conflicts and their implied human rights violations, the DPRK has argued that the international human rights mechanisms embraced by the United Nations reflect hypocrisy and double standards.

North Korea is opposed to international human rights mechanisms, stating that they threaten national sovereignty and dignity. Furthermore, the DPRK has repeatedly raised the human rights issue of the main actors involved-a kind of strategy of fighting fire with fire. On May 2014, North Korea submitted a document to the UN Human Rights Council that asserted how seriously South Korea and the United States violated the human rights of North Koreans. North Korea believed that South Korea and the United States joined Japan and the EU to oppress them by raising North Korea's violations of human rights in the UN. One

\footnotetext{
${ }^{4}$ See the Government of Democratic People's Repubic of Korea (2014).
} 
of North Korea's countermeasures has been to criticize the human rights situations in South Korea and the United States. This was exactly the same tactic used by China when it attacked the United States by releasing its "Human Rights Record of the United States." Similarly, North Korea released a paper titled "An Accusation of South Korea for Having the Most Serious Human Rights Situation in the World." Furthermore, North Korea critiqued the citizenship situation of the United States as being the worst in the world (Korea Central News Agency April 29, 2014).

The current human rights debate between North Korea and western countries is reminiscent of the one between the United States and the Soviet Union, and the one between North and South Korea, during the Cold War period. Even though Cold War adversaries for the most part achieved detente globally, the Cold War still exists in Northeast Asia. Therefore, it has been hard to escape a Cold War mentality when it came to security and human rights issues in the Korean Peninsula. The confrontation between universal and relative perspectives caused the politicization of human rights issues rather than any substantive improvements in human rights.

\section{THE EMERGENCE OF A NUCLEAR DIVISION SYSTEM}

With the division of the Korean Peninsula decided without the consent of the Koreans who lived there, the people were forced into a process that formed the Cold War system in East Asia (Cumings 2007, 21-42). North and South Koreans, as well as those overseas, then had come to recognize the division as an issue of national independence. From the beginning, the division split the nation based on an ideological confrontation, and North and South Korea up to the present continue to have a hostile relationship. As the division has lasted for almost seventy years following the end of the Cold War, North and South Korea appear to be two different countries, with that division resulting in each country taking on different characteristics (Park 2012, 37-72). While reflecting changes in the international system, the division system was said to reflect "the dynamics of the interface relationship between hostility and dependence" by the two divided states (Park 1997, 44). A central feature of the division system, North and South Korean relations have been widely considered as "hostile interdependent relations." (Lee 2000, 31-32)

The division system presents an obstacle in North-South relations, as well as in viewing the main actors as only existing within two divided regimes. There is also a problem with considering unification as the only way of overcoming the divi- 
sion system. In this limited discussion of the dynamics of international politics, which had formed and has contributed to the development of the division system, those dynamics are dealt with as external variables-or as part of the policy environment-because it is possible to ignore aspects of infiltration and internalization in the Korean Peninsula (Hong 2012). Interest in peace seems relatively weak in such an existing discussion. When considering the indivisibility of the Korean Peninsula and Northeast Asia, unification of the Korean Peninsula should be addressed in parallel to regional peace-building. Also, North and South Korean relations theory is based on the state power of North and South Korea because it has been easy to neglect the state-society relationship as well as the role of surrounding countries.

There have been several attempts to overcome the limitations of the theoretical perspectives of the division system. One is the "Division Violence" theory. Figuring out the violent character of the division system, Philo Kim (2014) clarified "division violence" as "a series of violence of life, exploitation, and mental oppression in any divided situation or in the name of division." Using Johan Galtung's model of triangular violence, Kim clarified that division violence had aspects of physical, structural, and cultural violence. The three areas where division violence is used do not relate only to relations between North and South Korea, but also to other nations in the international system surrounding the Korean Peninsula and various groups within division societies. In Kim's discussion, it was impressive that he linked division violence to "division peace." It is possible to define division peace as the exercising of rightful power to maintain a division. However, Kim did state that it is not easy to separate division peace from division violence. He accepted that "division violence is a concept of reflection which reveals the fiction of division peace" (Ibid.).

Second, a structure against peace in the Korean Peninsula has been proposed as an alternative discourse to the division system theory. Sugata Dasgupta (1967) used the term "peacelessness" in describing the lives of people living in third world countries and explored alternatives. Generally, war was the opposite of peace, but he defined "peacelessness" as the situation in which peace does not exist even in the absence of war. Dasgupta's peacelessness was a noticeable conceptualization of Galtung's structural and cultural violence; therefore, "peacelessness" was a critical-and alternative-term to existing peace theories. "Peacelessness" is a very useful term to a multi-dimensional understanding of violence in the Korean Peninsula. The structure against peace in the Korean Peninsula is a very difficult multi-dimensional concept to reduce it to merely North and South Korea relations. The Korean Peninsula is a complicated historical configuration created by actors and their interactions. Combining Dasgupta's peacelessness 
and Robert Cox's 'historical structure,' Suh explored the characteristics and patterns of Korean conflict (2012, 31-60).

Discussions on division violence and peacelessness in the Korean Peninsula have significance for overcoming existing limitations in discussions of the division system only in terms of the context of state initiatives and the finite North and South Korea relationship. However, they do not entirely turn attention away from static discussions of the division system. Because the division system is one with the armistice system, it continues to change. The division system not only adjusted to East-West detente at the beginning of the 1970s, but also lasted through the end of the Cold War in the early 1990s. Since the 2000s, the division system at times surely has not been stable (Paik 2011), but that instability did not have an effect on the roots of the system. Rather, the division system had assumed totally new characteristics by the 2010s. It reflected the emergence of a 'nuclear' division system.

The nuclear division system has slowly emerged after the international community missed two chances for denuclearization in the Korean Peninsula in the late 1990 s and in the mid-2000s. The nuclear division system is the result of not reverting to continuous mutual distrust between North and South Korea and the United States and the synergism of the arms race and the armistice system. In the context of a series of nuclear tests by North Korea, the hereditary succession of three generations of supreme leaders in the North, and increased military tensions in Northeast Asia, suggest many political reasons that the division system will evolve in new ways.

Meanwhile, the North Korean nuclear issue, or denuclearization of the Korean Peninsula, has been recognized solely as a security issue, and it has not been discussed in the sense of the division system. By conducting four nuclear tests, developing military technology, and declaring itself a nuclear-weapon state, the DPRK repeatedly has insisted upon nuclear disarmament talks with the United States. North Korea forcefully explained that their nuclear armament was an inevitable defensive action against "the U.S. hostile policy toward the Republic," and that nuclear weapons ultimately helped keep the peace in Northeast Asia (Korea Central News Agency 2010; Rodong Sinmun 2013a). Also, the regime of the current North Korean leader, Kim Jong-Un, has been attempting to recover from a weakened economic situation and develop a deterrence capability by adopting a new strategic line of "parallel economic construction and nuclear arms development." Kim asserted the primacy of national sovereignty in a speech in March 2013 at a plenary meeting of the Central Committee of the Korea Workers' Party: "The constant strengthening of our self-reliant defense capacity, with nuclear force at the core, constitutes a firm guarantee for protecting our right to sover- 
eignty and national existence as well as achieving national prosperity" (Rodong Sinmun 2013b). In accordance with Kim's stated priorities, unification discourses in North Korea have decreased and his leadership propaganda and criticisms of South Korea have increased. The main factors related to this are North Korea's nuclear capability reinforcement, continuous U.S.-South Korean joint military exercises, and the intensification of the hostile relationship between North and South Korea.

South Korea has stayed under the nuclear umbrella of the United States and maintained a confrontational military posture with respect to North Korea. By the 2000s, the alliance between the United States and South Korea had expanded globally and an alliance between the United States, South Korea, and Japan began to form to contain a rising China. Not only the information, communication and armament systems, but also the troops of the South Korean army have become more involved in the U.S. security system in the Asia-Pacific region and beyond. South Korea and the United States had decided to organize a coalition division by 2015, and it has become known for such missions conducting operations related to civilian affairs and eliminating weapons of mass destruction in North Korea. This coalition division means mixed forces at the brigade-level of the Korean army conduct operations with the U.S. 2nd Infantry Division (Yonhap News September 4, 2014). For the purposes of preparing for possible North Korean missile attacks and the growing Chinese military threat, in early 2016 South Korea and the United States formalized the discussion of South Korea's participation in the U.S. missile defense system and ROK has attempted to exchange military information with Japan using the framework of triangular military cooperation. As compensation for its cooperation, South Korea continues to be under the U.S. nuclear umbrella. Officials in Seoul and Washington also took deferral of the transfer of operational command authority of the South Korean army for granted. George W. Bush, who designated North Korea as part of an "axis of evil" and expressed willingness to execute a nuclear preemptive attack, indicated that he would confront former DPRK leader Kim Jong-Il in his final term. With the inauguration of the Obama administration, however, the United States changed its policy toward North Korea to "strategic patience," which entailed dealing with the hostile country by not dealing with it. As a result, denuclearization in the Korean Peninsula has drifted further away from achieving success. When North Korea increased its nuclear armament capability to counter a hostile U.S. policy toward the country, the United States expanded its alliance with South Korea and Japan in the form of a triangular military cooperation regime in response to perceived North Korean and Chinese threats. The nuclear division system has become both the byproduct and the driving force of this intractable security 
dilemma in Northeast Asia.

While the nuclear division system delays resolution of the remaining holdout in the Cold War structure in Northeast Asian, it has been shown to promote militarism in denuclearized South Korea and Japan. North Korea's nuclear weapons capability seems to reflect the firmness of the division system, while encouraging South Korea's embrace of the U.S. nuclear umbrella in a qualitatively different way.

\section{THE SYNERGISM OF HUMAN RIGHTS POLITICS AND MILITARISM}

\section{POLITICIZATION OF HUMAN RIGHTS}

The difference in human rights perspectives between North and South Korea has contributed to the politicization of human rights issues. If one side raises the other's human rights record, it can become a point of dispute depending on how the issue is approached. When the South Korean government raised the issue of human rights in North Korea, the North Korean government's response depended on the overall tenor of North-South relations and South Korea's policy direction.

The Kim Dae-jung and Roh Moo-hyun governments promoted human rights and were highly acclaimed at home and abroad. Both governments pushed forward with an engagement policy toward North Korea and concentrated on improving the relationship and establishing a peace regime in the Korean Peninsula. The Kim Dae-jung and Roh Moo-hyun governments recognized that the North Korean human rights issue was of dire international concern. It was then thought that South Korea, as a member of the international community, had a duty to participate by actively promoting human rights in North Korea. Simply put, the approach of both governments had strategic features with respect to the North Korean human rights issue. For example, considering the overall target of Kim and Roh's rapprochement policy toward North Korea, the two former presidents expected a reduction of tensions in the Korean Peninsula and inter-Korean reconciliation and cooperation that would contribute to human rights improvements for North Koreans. Both governments provided humanitarian assistance for North Koreans' right to survival, preserved "quiet diplomacy" for the safe entrance of North Korean escapees in South Korea, established a resettlement support system to protect North Korean escapees, and approached the issue of civil and political rights for North Koreans indirectly through international organizations and non-governmental organizations (Ministry of Unification 2003; 2007). Furthermore, both governments frequently held reunions for separated 
families. Through continuous conversations between authorities of the two Koreas, a designated meeting room at Mount Geumgangin North Korea was established for the frequent reunions of families separated since the Korean War. In addition, both governments allowed North Korea to recognize the existence of abductees in the North from the Korean War, POWs detained in North Korea, and pushed forward on these subjects within the framework of the reunion meetings. However, South Korea was inconsistent in its voting on UN resolutions on North Korean human rights, and during this period the South at times did not participate because the direction of the policy toward North Korea shifted focus to denuclearization in the Korean Peninsula.

North Korea did not spark a conflict with the South Korean government with regards to the human rights issue during the two administrations. The exception to this was in July 2004, when the Roh government openly took in about four hundred North Korean escapees who had been staying in Vietnam, and the North Korean government ceased talks with South Korea for one year. During this period, the ROK government and the ruling party also came in conflict with the conservative opposition party regarding the North Korean human rights issue. After a North Korean human rights law was enacted in the United States and Japan in 2004 and 2006, respectively, the conservative opposition party, the HannaraParty (now SaenuriParty) and North Korean human rights organizations tried to enact a North Korean human rights law. However, both governments concluded that the law would draw strong opposition from North Korea and fail to achieve actual human rights improvements.

In contrast, the Lee Myung-bak administration's stance was that "human rights is a universal value and therefore should be dealt with separately from other agendas(in inter-Korean relations)." 5 Despite the stances of the two previous administrations, the Lee administration voted consistently in favor of UN resolutions on North Korea's human rights violations. Lee's policies resonated with the international community, but as a result those policies led to the deterioration of inter-Korean relations. Emphasizing the universality of human rights did not lead to any practical strategies for improving the human rights situation in North Korea (Suh 2013, 85). The Park Geun-hye government is taking the same policy approach toward North Korean human rights as her predecessor. The Park government has actively participated in voting for UN resolutions on North Korean human rights, has succeeded in enacting the North Korean human rights law, and

${ }^{5}$ A comment at the briefing of Cho Hui-yong, spokesperson of the Ministry of Diplomacy and Trade on March 4, 2008, when Lee Myung-bak government joined the international attempt to bring in a DPRK human rights resolution to the UN Human Rights Council (Yonhap News March 4, 2008). 
has not provided direct government-sponsored humanitarian assistance. Far from meaningful cooperation between North and South Korea in the area of human rights, the Park government has not engaged in continued mutual dialogue. While the Park government promoted a "unification is a great success" discourse and set up the Unification Preparatory Committee, the regime had difficulty in implementing policies aimed at improving North Korean human rights proactively because of domestic issues, such as the Sewol ferry accident and a more general downturn in the economy, as well as North Korea's antagonistic actions. The biggest and most serious problem in the Lee and Park governments has been that they recognized the North Korean human rights issue as being equal to the notion of the universality of those rights and their relationship to international cooperation, while simultaneously ceasing talks and cooperation with North Korea. In the meantime, a nuclear-armed North Korea has insisted that human rights were equal to state rights and has responded to external political pressure from the South.

The South Korean government has continued to support the increasing pressure on North Korea placed by the international community. As a result, North Korea has strongly opposed that pressure, and it appears that practical improvements in North Korea's human rights situation will continue to be a challenge. The politicization of human rights, in which political pressure brings about a boomerang effect, has had a noticeable impact on the issue of North Korean human rights.

\section{THE DEVELOPMENT OF MILITARISM}

When looking at the Korean Peninsula only from the perspective of a security dilemma, it is hard to explain why military tensions have lasted for almost seventy years. It may be that the security dilemma is an unintended result of rational decision-making. Self-defense efforts for national survival have not been coordinated. The will and power to form and maintain the division-armistice system are important to consider, in addition to the security dilemma in the Korean Peninsula. Here, the distinction between the military and militarism is crucial.

A pioneer of the theory of militarism, Alfred Vagts wrote, "Militarism presents a vast array of customs, interests, prestige, actions, and thought associated with armies and wars and yet transcending true military purposes" $(1959,13)$. Vagts distinguished militarism from "the military" by noting that the military was "marked by a primary concentration of men and materials on winning specific objectives of power with the utmost efficiency." He characterized militarism such that it may permeate all society and become dominant over all industries and arts. Exceedingly large military expenses, a military way of thinking, customs extend- 
ing beyond the military, and military approaches towards all issues of international politics collectively are considered to be features of militarism (Regehr 1980, 131-136). Chalmers Johnson similarly described the difference between the "military" and "militarism" (2004, 23-24). The military encompasses all the activities, qualities, and institutions required by a nation to fight a war in its defense. A military should be concerned with ensuring national independence, a sine qua non for the continuation of sovereignty. Militarism, however, is the phenomenon by which a nation's armed services come to put their institutional preservation ahead of achieving national security or even a commitment to the integrity of the governmental structure of which they are a part. Johnson (Ibid., 284-285) said that the imperialism and militarism of the United States have brought sadness to the country, and this sadness specifically was generated from being in a state of permanent war, the loss of democracy, the spread of war and a demagogical system, and economic collapse. However, the fixation to maintain the authority and reputation of the United States as an empire causes or enhances conflicts all around the world. The Korean Peninsula and the Middle East are representative examples of U.S. militarism.

Despite the differences of degree, both Koreas are thoroughly militarized societies. Enshrined in statutory form in its constitution, North Korea's SongunSasang (military first thought, 先軍思想) is central to the militaristic development of North Korean society. The unstable economic situation in the DPRK notwithstanding, its military expenses represent roughly 20 percent of its national budget-a huge percentage of its overall government spending. That North Korea's constitution stipulates the unity of the military and its citizens according to collectivist principles bespeaks the degree to which military culture is sanctioned.

Yet that enshrinement of militarism as a national prerogative is not exclusive to North Korea. Despite its legacy of having overthrown military dictatorships and been extolled internationally for being a vibrant democracy, South Korea has been criticized by pacifist and feminist groups for being a society thoroughly penetrated by militarism (Lee 2012; Kwon 2000). Over thirty times the size of North Korea's national defense budget, South Korea's military budget vastly dwarfs that of most countries. According to the SIPRI report, from 2004 to 2013, South Korea rose to become the fourth largest national importer of weapons and the tenth largest state in terms of military spending (Perlo-Freeman and Solmirano 2014, 188). Critics have pointed out that South Korea's arms escalation serves the neoCold War U.S. strategy of containing China. Under an alarmist cover of national security, the South Korean government has not only spent astronomical sums on importing arms but has also allowed its military policy to remain virtually 
unchecked by civilian control and good governance.

In addition, as the country that outspends all other nations combined when it comes to the world's arms budget, one that leads the charge in most contemporary international conflicts and has the greatest stake in supporting its militaryindustrial complex, the United States cannot be omitted from discussions of 'Korean' militarism. From the division of the Korean Peninsula, which precipitated the Korean War as a civil war of national reunification, to the present, the United States has been continuously invested in the maintenance of an ongoing hostile situation in the Korean Peninsula. In this context, the one-sided U.S. critique of North Korean human rights may fundamentally obscure the historical and structural responsibility of the United States for the North's human rights problems, both past and present. Militarism in the Korean Peninsula implicates not only South and North Korea and their hostile interactions with each other, but also the United States, whose long-term involvement and intervention have destabilized both Koreas and the wider region (Suh 2014, 7-8).

Although national security-based conventional security discourse is prevalent and has influence, it obscures the context of the Korean Peninsula's complex underlying intra-regional security dynamics by focusing on North Korea as the source of most of the region's troubles. Such an approach reduces knowledge about complex security problems to a "one cause fits all" diagnosis (Smith 2007, $3-5$ ). In approaching North and South Korean relations through the application of security theory, the main target of interest is not only the ruling territory of both countries, but also the guarding of the ruling ideology, and the matter of utmost concern is the defense of the territory and social order protection, with states the main actors and military power, alliances and negotiations the means of control. It is inevitable that the management of North and South Korean relations, or the policy of one towards its enemy, is based on a national security framework in a situation of division, considering the hostility and confrontation between North and South Korea. In the case of approaching North and South Korean relations depending on national security, the values that are absolutely necessary to improving the quality of people's lives, such as human rights, sustainable development, and welfare, are unfortunately damaged. Within the view of national security theory in actuality, both divided powers have caused a decrease in the quality of people's lives. Fundamentally, not only are North and South Korean relations viewed in terms of national security theory, but also the survival and peace of the public have been destabilized. There are reasons to turn away from militarism to ensure sustainable peace in the Korean Peninsula. Rapid changes in, or outside of, the Korean Peninsula, such as democratization, a lull in the Cold War, and globalization, also have given the international community a chance to 
deal with North and South Korean relations from different points of view (Kim 2000; Park 2011, 207-231).

If advances in inter-Korean relations can impact the human rights situations of the two Koreas for the better, militarism is a variable that unquestionably transforms the human rights situation for the worse. Uniquely bound by a hostile interdependence, South Korea and North Korea require a comprehensive human rights approach that does not isolate one or the other for censure. Such an approach would necessitate a reckoning with the obstacles that militarism poses to the simultaneous and integrated progress of human rights in the peninsula as a whole (Suh 2014, 10). Although the aspects and the degrees are different, the accelerating forces of militarism have continued on the entire Korean Peninsula under the division-armistice system. Politicization of human rights, a nuclear division system, and militarism as an extreme type of security dilemma explain how human rights and security have taken wrong turns in the Korean Peninsula and produced a negative synergistic effect from the beginning. In contrast, is it possible to build a complementary relationship that takes human rights and security in a positive direction?

\section{THE MOTIVE OF TRANSFORMATION}

There are two ways for human rights and security to build a complementary relationship in both theory and practice. One includes peace and security in human rights and another embraces human rights in peace. Expanding the category of human rights to include a 'right to peace' rejects the confrontation of human rights perspectives surrounding the first- and second-generation conceptualizations and helps to promote the equal recognition of human rights and peace. Transforming national security into human security, or at least coordinating the two kinds of security, helps the security issue enhance and promote civilian control and reconcile both security and human rights. The rights-based approach $(\mathrm{RBA})^{6}$ to human security is a part of the right to peace, with the right to live in a safe and healthy environment, the right to sustainable development, the right to civil disobedience and to conscientious objection, the right to resist and oppose oppression, and the right to disarmament.7 The right to peace and the RBA to

\footnotetext{
${ }^{6}$ See "The UN Statement of Common Understanding on Human Rights-Based Approaches to Development Cooperation and Programming" (November 28, 2015).

7 See "Santiago Declaration on the Human Rights to Peace" (December 9-10, 2010). The Declaration is adopted at the International Congress on the Human Right to Peace.
} 
human security are alternative discourses to create positive synergetic effects beyond the current distortion of human rights and security. The interaction of human rights and security based on democratic governance ensures the positive synergistic effects of both norms. Then what change is possible if we apply both the right to peace and the RBA to human security to the Korean Peninsula?

\section{RIGHT TO PEACE}

The right to peace can be defined as the right of the people to engage in peaceful lives without violence in a negative dimension, and, the rejection of structural and cultural violence that undermine peace and sustainable life against violence and war in a positive dimension. The negative way of the right to peace in the Korean Peninsula indicates the right to peace and security through the opposition of war and the threat of war and the peaceful settlement of disputes. The negative way of the right to peace in practice is possible when there is peace between the North and South following transition to a peace system from the existing armistice system and the denuclearization of the Peninsula. Here, it is important for the core rights supporters, who are key actors in the process of establishing the right to peace, to promote and discuss the mutual roles clearly and also enhance interactions to achieve positive results. It is necessary to revitalize cooperation through both bilateral and the six-party talks among the major actors concerned. It is also necessary for rights supporters to urge the parties to live under the right to peace. Given that the situation in the Korean Peninsula does not recognize the right to peace, education on what is a right to peace should come first.

There is no value difference between negative peace and positive peace. Rather, there is a need to pursue congruently two real peace situations in the Korean Peninsula. It is likely that there will be doubts surrounding the feasibility of the positive right to peace, and in the situation of the division of the peninsula, 'negative peace $=$ security.' The proposition is that the division cannot preserve entirely human rights and democracy, which have been practically justified since South Korea's 1987 democratization. The necessity of views on peaceful reunification and realization of the need to visualize the universal values of human rights in the Korean Peninsula has increased. The positive right to peace has significant meaning that contains the exclusion of armaments possession, the exclusion of obstructive behaviors to peace by other nations (for example, through arms exports), the right to nonparticipation in military activities to uphold the individual's right to a freedom of conscience and religion, the prohibition of the limit on basic rights due to military purposes (for example, the attachment of property or a limit on the freedom of expression), and right to live out of the shadow of war in this context. Here, transparent military security policies and the right to 
the participation of citizens belong to the positive side of the right to peace. This provides an opportunity to reevaluate the U.S. armed forces in Korea and their base operations, arms introduction projects, redeployment policies, the construction of military bases, general policies toward North Korea, and policies for the dispatch troops. In Korea, the right to peace does not pertain to domestic political dynamics alone, but also involves the relationship between North and South Korea and various security issues in the Korean Peninsula (Aasen et al. 2001; Park 2007; Liem 2014, 113-126).

To check the validity of the right to peace in the Korean Peninsula, it is necessary to approach the right to peace from both levels mentioned above at the same time, reflecting the stances and understandings of individuals and groups as rights beneficiaries. At an early stage, it is encouraging to note that, currently, local governments, experts, and civil society organizations in Korea have begun to show an interest in the right to peace. Discussions on the right to peace initiated by not only UNESCO ${ }^{8}$ but also a number of specialist groups all around the world, have expressed the view that local assemblies and civil society organizations are expected to have an impact (UN Human Rights Council 2011; UN General Assembly 1999; Roche 2003). The most important undertone of the development of the right to peace in the Korea Peninsula is what type of peace best supports human rights. And yet, there is the issue of si vis pacem, para bellum, or the impact of the established principle of 'peace by force' among surrounding countries, especially North Korea. Is it possible to overcome a series of militarisms in and around the peninsula when peacefully transforming an authoritarian state into a democracy and establishing a regional peace system at last?

\section{HUMAN SECURITY}

If we look at inter-Korean relations from the perspective of the needs of human security, what difference will this have on the national security framework? If we view North and South Korean relations theoretically through the lens of human security 1) the concerns are the necessity of the public, such as economic development and human rights; 2) the relevant issues range over seven areas, such as food, health, the environment, the economy, personal integrity, community, and political security; 3) the main actors are (inter-)governmental organizations, non-governmental organizations, and local communities; and 4) the means to achieving such security are human development, human rights education, polit-

\footnotetext{
${ }^{8}$ See UNESCO “UNESCO's Work on Education for Peace and Non-Violence." For more information on UNESCO's peace education, see http://www.unesco.org/new/en/unesco/resources/ (December 15, 2015).
} 
ical development, and public participation among others. Looking to the future of inter-Korean relations based on this, we can see a qualitative change in interKorean relations. The reconfiguration of inter-Korean relations according to the dictates of human security theory should be away from state-centric policies to those that are public-centric, and the state has to form partnerships with nonstate actors during such a transition (Tadjbakhsh and Chenoy 2007, 176-183; Fouinat 2004, 290-291).

As long as the division exists and the regional arms race continues, of course the fundamental question of whether human security is really possible in the Korean Peninsula will continue to be raised. This theory of human security emphasizes an alternative security process that sits somewhere between optimistic ideals and fundamental doubts. Therefore, human security needs to set up stages, such as inter-Korean relations, early reunification and resolution of the conflict situation, and reunification achieved with appropriately realistic strategies. Observing North and South Korean relations through the perspective of human security gives prominence to coexistence, cooperation and prosperity beyond the confrontations between the two states.

Due to mutual distrust based upon opposing political systems, it would be difficult to apply principles related to both inter-Korean personal security and political security to other areas at the same time. It is required for the two Koreas to approach national security and human security more carefully, not just because both 'securities' in theory are closely related (Smith 2005), but because they are also equally crucial in the context of the protracted conflict and fragile peace on the Korean Peninsula. When we deal with the nuclear issue from the perspective of national security, on the one hand, the focus has been on North Korea's nuclear armaments. On the other hand, if we approach the issue from the perspective of human security, it can be extended into denuclearization throughout the entire peninsula covering both nuclear armament and nuclear power generation. The efforts to improve human security between the two Koreas provides an opportunity to explore policies toward North Korea in new terms of promoting the quality of people's lives more effectively rather than taking the approach informed by a national security paradigm. Also, by developing the relations between North and South Korea and promoting their peaceful coexistence, it will be possible to pursue political security.

First of all, for the human security approach to be initiated on both sides of the peninsula's 38 th parallel, North and South Korea have to expect some benefits as a result of cooperation. North Korea has limitations in the management of its state because of its chronically under performing economy and isolation from the international community. In this situation, North Korea has implemented the 
"military first policy," clearly placing limits on the potential for reform. Given this, a favorable diplomatic environment and international relations are crucial for the North's normal national development. The main countries with which the DPRK has ongoing diplomatic relations or negotiations are China, the United States, Japan and South Korea. In order to extricate itself from antagonistic relations with South Korea, North Korea has attempted to establish and maintain good relations with-and cooperate with-China and Russia, and also has taken steps to improve relations with Japan and the United States. However, it is impossible to have better relations with the latter two countries without improving relations with South Korea. The most important consideration for North Korea is whether South Korea will pursue unification through absorption. As a non-political approach, cooperation between North and South Korea through the enactment of a 'human security' paradigm is of interest to North Korea.

It is impossible to talk about human security from the beginning. In this situation, even as the United Nations and other relevant international organizations hold a meeting titled with 'Promoting Human Security in the Korean Peninsula: Vision and Strategy,' they can play the role of facilitator. Humanitarian assistance and economic development-focused cooperation will contribute to improving the human security of North Koreans and promote the existence of a cooperative relationship between North Korea, South Korea, and other regional and global actors. By doing this, the international community can lead in the direction of increasing cooperation to develop universal values, such as peace, human rights, sustainable development and humanitarianism in the peninsula.

The reconfiguration of inter-Korean relations through human security is very meaningful in the context of 1) establishing peace and stability in the Korean Peninsula, 2) increasing inter-Korean economic cooperation and cultural exchanges, 3) extending international engagement in, and cooperation with, the DPRK, and 4) laying the foundation for peaceful unification. Besides this, the reconfiguration of the relationship between the two Koreas through human security will help bring about improvements in civilian control and encourage North Korea to put greater priority on policies that enhance public life and civil participation. When reconfiguring North and South Korean relations, the most important issues are increasing civil participation while guaranteeing the North's national interests. The diverse private sectors include business, dispersed families, religion, art, sports and academia. In terms of the attributes of human security, private-sector actors can participate in developing the relationship between North and South Korea as main agents, not as only assistants of the government. 


\section{CONCLUDING REMARKS}

Why is the Korean conflict proving so intractable? In part, it is because the Korean conflict reflects various contradictions from which humans have suffered throughout the modern history of international relations. Also, political forces, which have not only existed in, but also crossed the Korean Peninsula, have advocated for maintaining their vested interests in keeping the division and pursuing those unjustifiable interests. Therefore, attempting to understand the Korean conflict by reducing it to merely the relationship between the North and the South may provide a narrow view of the actual picture. The prolonged division of the Korean Peninsula has been characterized by the existence of forces that still support the division of the Peninsula by reproducing distrust and a sense of animosity. The confrontations and conflicts on human rights between the two Koreas are remnants of the Cold War, and the continuation of the division system together with the armistice has developed further into a nuclear conflict in the regional political system. This has been used as a cause for various national security policies by the vested rights forces. The politicization of human rights is only a reflection of the long-term division of the peninsula.

If division and war are the result of individual actions, it is also possible for individuals to achieve settlement and peace through their efforts. We can search the motives to reduce the politicization of human rights and curtail the rising militarism by promoting more active roles for the two Koreas to lead a campaign of international support. The right to peace and human security may be good alternative solutions. Given the current segmented system, it will be hard to realize a lasting vision of human security and the right to peace in the political reality of Northeast Asia. As a first step, changing our understanding of human rights and human security is imperative. Creative practice comes from the freedom of imagination. Communication, assistance, and exchange today could bring about meaningful change towards realizing the positive synergistic effects of human rights and human security in the Korean Peninsula.

\section{REFERENCES}

Aasen, Henriette Sinding, Uichol Kim and GeirHelgesen eds. 2001. Democracy, Human Rights and Peace in Korea:Psychological, Political and Cultural Perspectives. Seoul: KyoyookKwahaksa.

Bernaldez, Pedro B. 2011. "Human Security in Global Governance: Implications for the East Asian Region Focusing on South Korea." OUGHTOPIA 26 (2), 5-31. 
Chosun Human Rights Association. 2014. "A Report of Chosun Human Rights Association.” Accessed at http://m.cafe.daum.net/sisa-1/jZfp/1190?list URI=\%2Fsisa-1\%2F_rec (April 10, 2015).

Cumings, Bruce. 2007. "Creating Korean Insecurity: The US Role.” In Hazel Smith ed., Reconstituting Korean Security: A Policy Primer, Tokyo: United Nations University Press, 21-42.

Dasgupta, Sugata. 1967. "Peacelessness and Maldevelopment: A New Theme for Peace Research in Developing Nations." Paper presented at the International Peace Research Association (June 17-19).

Fouinat, Francois. 2004. "A Comprehensive Framework for Human Security." Conflict, Security and Development 4(3), 289-297.

Hong, Seukryule. 2012. Hysteria of Division. Paju: Changbi.

Hunt, Lynn. 2008. Inventing Human Rights: A History. New York: W. W. Norton \& Company.

Ishay, Micheline R. 2008. The History of Human Rights: From Ancient Times to the Globalization Era. Los Angeles: University of California Press.

Johnson, Chalmers. 2004. The Sorrows of Empire: Militarism, Secrecy, and the End of the Republic. New York: Metropolitan Books.

Kim, Philo. 2014. "Peacelessness in the Korean Peninsula and Division Violence." Paper Presented at the Workshop of 'Division Violence' Organized by the Institute for Peace and Unification Studies (IPUS) of Seoul National University (August 20).

Kim, Samuel S. ed. 200o. Korea's Globalization. Cambridge: Cambridge University Press.

Kwon, Insook. 2000."Militarism in My Heart: Militarization of Women's Consciousness and Culture in South Korea." Ph.D. Dissertation, Clark University.

Korea Central News Agency. 2010. "We Have Thousands of Rightful Reasons to Maintain the Nuclear Deterrence." (October 23).

Lee, Jong-seok. 2000. Newly Written Understanding of Current North Korea. Seoul: Yuksabipyungsa.

Lee, Kyoung-Joo. 2014. Understanding Rights to Peace: Concept, History, Analysis, and Application. Seoul: Sapyoung Academy.

Lee, Shin-wha. 2008. "Nontraditional Security and Regional Cooperation in Northeast Asia." Korean Political Science Review 42(2), 411-434.

Lee, Taeho. 2012. "The Armistice in the Korean Peninsula and Korea-US-Japan Trilateral Military Alliance." Paper presented at the 3rd International Workshop for Peace and Disarmament in the Asia-Pacific Region (November 27). 
Liem, Paul. 2014. “Peace as a North Korean Human Right.” Critical Asian Studies 46(1), 113-126.

Lim, Jae-sung. 2011. "The Right to Peace, Human Rights from the Grassroots Up: Focused on 'Right to Peace' Discourses by Korean Social Movements." Economy and Society 91, 167-210.

Ministry of Foreign Affairs of Korea. 2016. "Human Rights Diplomacy.” Accessed at http://www.mofa.go.kr/ENG/policy/humanright/overview/index. jsp?menu=m_20_6o_10 (April 3, 2016).

Ministry of Unification of Korea. 2003. 2003 Unification White Paper. Seoul: Ministry of Unification of Korea.

. 2007. 2007 Unification White Paper. Seoul: Ministry of Unification of Korea.

Paik, Nak-chung. 2011. The Division System in Crisis: Essays on Contemporary Korea. Los Angeles: University of California Press.

Park, Ihn-hwi. 2011. "Korea's National Interests and Security Conditions in the Age of Globalization.” The Korean Journal of International Studies 9(2), 207-231.

Park, Kyung-seo. 2007. Promoting Peace and Human Rights in the Korean Peninsula. Seoul: Ewha Womans University Press.

Park, Myoung-kyu. 2012. Sociology of the Boundary between North and South Korea. Paju: Changbi.

Park, Myoung-kyu, Philo Kim, Young Hoon Song, Yong Seok Chang, and EunmeeJeong. 2013. 2013 Research on Unification Awareness. Seoul: IPUS, Seoul National University.

Park, Myung-rim. 1997. "The Structure and Change of Division Order: The Dynamics of the Interface Relationship between Hostility and Dependence, 1945-1995." National Strategy 3(1), 41-79.

Perlo-Freeman, Sam and Carina Solmirano. 2014. SIPRI Yearbook 2014: Armaments, Disarmament and International Security. Oxford: Oxford University Press.

Regehr, Ernie. 1980. "What is Militarism.” In Asbjørn Eide and Marek Thee eds., Problems of Contemporary Militarism. New York: St Martin's Press, 127-139.

Rodong Sinmun. 2013a. "Report on the March Plenary Session of the Central Committee of the Korea Workers' Party." (April 2). . 2013b. "Self-Preserving Nuclear Deterrence is the Best Property of Our Country." (March 13).

Roche, Douglas. 2003. The Human Right to Peace. Ottawa: Saint Paul University. International Congress on the Human Right to Peace. 2010. "Santiago Declaration on the Human Rights to Peace." December 9. 
Smith, Hazel. 2005. Hungry for Peace: International Security, Humanitarian Assistance, and Social Change in North Korea. Washington, D.C.: United States Institute of Peace Press. . 2007. "Reconstituting Korean Security Dilemmas." In Hazel Smith ed., Reconstituting Korean Security: A Policy Primer, Tokyo: United Nations University Press, 1-20.

Suh, Bo-hyuk. 2012. "Why Robert Cox Has Been to the Military Demarcation Line?: The Structure Against Peace and Its Operational Pattern in the Korean Peninsula." Korea and World Politics 28(3), 31-60. . 2013. "Beyond Silence and Blaming: Revisiting South Korea's Role in North Korean Human Rights." Asian Perspective 37(1), 77-97. . 2014. "The Militarization of Korean Human Rights: A Peninsula Perspective." Critical Asian Studies 46(1), 3-13.

Tadjbakhsh, Shahrbanou and Anuradha M. Chenoy. 2007. Human Security: Concepts and Implications. New York: Routledge.

The Government of Democratic People's Republic of Korea. 2014. "Letter dated 3 February 2014 from the Permanent Representative of the Democratic People's Republic of Korea to the United Nations Office at Geneva Addressed to the President of the Human Rights Council." A/HRC/25/G/6 (February 12).

UN General Assembly. 1999. "Declaration and Programme of Action on a Culture of Peace.” A/53/243 (October 6). Accessed at http://www.unesco.org/ cpp/uk/declarations/200o.htm (December 1, 2015)

UNESCO. 2008. "UNESCO's Work on Education for Peace and Non-Violence." ED-2008/WS/38. Paris. Accessed at http://unesdoc.unesco.org/ images/0016/001607/160787e.pdf (December 1, 2015)

UN Human Rights Council. 2011. "Progress Report of the Human Rights Council Advisory Committee on the Right of Peoples to Peace." A/HRC/17/39. March 28.

Vagts, Alfred. 1959. A History of Militarism (Revised Edition). New York: Meridian Books.

Korea Central News Agency. 2010. "We Have Thousands of Rightful Reasons to Maintain the Nuclear Deterrence." (October 23).

Yu, Hyun Seok. 2011. "The Military and Human Security: Theory, Cases and Policy Implications for Korea." Korean Political Science Review 45(5), 221-241.

Yun, Byung-se. 2014. "Statement by H.E. Yun Byung-se, Minister of Foreign Affairs of the Republic of Korea." 25th Session of the UN Human Rights Council. March 5 . 